\title{
FORMULAIC STRUCTURE IN THROUGH THE LOOKING GLASS BY LEWIS CARROLL
}

\author{
Zafirna Arrofifah
}

Universitas Jember, Jember, Indonesia

Email: applefirna@gmail.com

Hat Pujiati

Universitas Jember, Jember, Indonesia

Email: hatpujiati.sastra@unej.ac.id

Irana Astutiningsih

Universitas Jember, Jember, Indonesia

Email: irananingsih@gmail.com

Article history:

Submitted Oct 28, 2020

Revised Nov 12, 2020

Accepted April 14, 2021

Published June 29, 2021

\begin{abstract}
This article focuses on the formulaic stucture in a popular children's literature entitled "Through the Looking Glass" by Lewis Carroll. This is aimed to analyze the formulaic stucture of the novel and the elements that caused the novel to become a popular children's literature in Victorian era, which is undoubtedly related to the Victorian values in Britain.Formula theory by John G. Cawelti is used to analyze the novel. The story of the novel is about a little girl named Alice who wants to be the queen when she is stranded in another world called Looking Glass after leaning into a mirror in her painting room. Result of this research shows that Lewis Carroll's "Through the Looking Glass" is written using adventure typologyshown through a hero with a goal to reach. The novel also uses fantasy and Victorian era setting to support the suspense.Furthermore, what made the story popular in the era is the need of escape provided by the novel for Victorian children through Alice's adventure.
\end{abstract}

Keywords: adventure; children's literature; formula; popular; scapism

\begin{abstract}
ABSTRAK
Artikel ini fokus kepada struktur formulaik dalam sebuah karyasastra anak yang berjudul Through the Looking Glass oleh Lewis Carroll. Tujuan dari penelitian ini adalah untuk menganalisis struktur formula pada novel dan juga unsur-unsur yang membuat novel ini menjadi sebuah karya sastra anak yang populer pada era Victoria yang berhubungan dengan nilai-nilai Victoria di Inggris. Teori formula yang dicetuskan oleh John G. Cawelti digunakan untuk menganalisis novel. Novel ini berkisah tentang seorang gadis kecil bernama Alice yang ingin menjadi ratu saat dia masuk ke dunia
\end{abstract}


Zafirna Arrofifah, Hat Pujiati, Irana Astutiningsih - Formulaic Structure in Thriugh the Looking Glass by Lewis Carroll

lain yang disebut sebagai Looking Glass setelah menyandarkan diri ke cermin di ruang menggambarnya. Hasil dari penelitian ini menunjukkan bahwa Through the Looking Glass oleh Lewis Carroll ditulis menggunakan tipologi petualangan yang dalam ceritanya selalu ada pahlawan yang memiliki tujuan akhir untuk dicapai. Novel ini juga menggunakan fantasi dan setting era Victoria untuk mendukung ketegangan cerita. Tidak hanya itu, yang membuat cerita ini populer pada era Victoria adalah kebutuhan eskapis pada anak-anak di era Victoria melalui petualangan Alice.

Kata kunci : petualangan; karya sastra anak-anak; formula; populer; eskapisme

\section{INTRODUCTION}

Children's literature reaches its golden age in Victorian era when a lot of writers and prominent ones sprung up through the subsidy of the publishing house in producing the books by ignoring the expensive revolutionized industry and paid more attention to the increasing literacy from the people, readers all range of ages and social classes had access to at least one literary work (Stevenson, 2011). One of the famous children's literary works from Victorian era that breaks through every generation is Through the Looking Glass, written by Charles Lutwidge Dodgson, using Lewis Carroll as a penname, in 1871.Originally, it is a sequel from Alice in Wonderland, a notable children's literary work issued out in 1865. This sequel was written when Dodgson taught Alice Liddell and her two sisters, Edith and Lorina, a game of chess. The sequel garnered a lot of attention, just like its predecessor, Alice in Wonderland. This time, there even was a stage play adaptation for Through the Looking Glass in April 1887. Nearly to hundred years later, Through the Looking Glasshad been adapted into many different medias, for example Alice Through the Looking Glass adaptation in 1962 where Judi Rolin played as Alice, TV movie is made and starred Sarah Sutton as Alice in 1974, Kievnauchfilm studio made a 38 minutes cutout animation and directed by Yefrem Pruzhanskiy in 1982, a drama radio on Saturday Drama and it was released online by BBC in 2012, and last the most streaking adaptation was in 2016, a film adaptation by Tim Burton. Nevertheless, this shows that Through the Looking Glass still has fame even in nowadays society, not much different than in that Victorian era. 
The novel is about a little girl named Alice who enters another world called Looking Glass world through a melting mirror. After knowing the land rules under the rules of a chess game where she can be a queen through several movements, she decides to be the queen alongside Red Queen and White Queen. Her adventure is not as easy as she thinks because she meets creatures that tend to belittle her and question her existence in this world. However, she manages to be the queen when she reaches Eight Square, yet when she is about to be coronated, she has to get the queens acknowledgement first and a commotion happens, waking her up from her dream.

This book was written in Victorian era, in which usually the book written in this era is filled with religious and moral tracts (Banerjee, 2007). Although, Through the Looking Glass was written in a bit different from the stereotype of children's literature in the Victorian era. The protagonist is depicted as rebellious and curious, given she is inside a world where she is not familiar with. In spite of this, a lot of people in Victorian era loved the novel, even the queen herself and had a stage adaptation that was performed throughout several places in the country. This statement raises several questions, but the more prominent one is the popularity of the book in the slightly different trope, unlike the usual children's literature in Victorian Era. This matches the characteristic of Formulaic Literature-escapism as stated by John G. Cawelti on his book Adventure, Mystery, and Romance: Formula Stories as Art and Popular Culture (1976).

The previous researches tend to focus on the utopian world constructed in the story (MacDonald, 1989), how the logic and the language present the fantastic world (Sparks, 1961)and analyzing the story in a content analysis that focus on theme (Morton, 1960). Most of the research on Through the Looking Glass neglects the relation of the formula that structure the story and its context. The glory of Victorian era is traced in the newness of the literariness as John G. Cawelti postulates in his Adventure, Mystery, and Romance: Formula Stories as Art and Popular Culture. Therefore, this researchdiscusses the Formulaic Structure in 
Zafirna Arrofifah, Hat Pujiati, Irana Astutiningsih - Formulaic Structure in Thriugh the Looking Glass by Lewis Carroll

Through the Looking Glass by Lewis Caroll to discuss the formulaic structure in the novel and the popularity the book received in Victorian Era by using formula theory by John G. Cawelti.

\section{THEORY AND METHOD}

\section{John G Cawelti's Literary Formula}

Cawelti's book Adventure, Mystery, and Romance: Formula Stories as Art and Popular Culture presents a thinking if literary formula is a narrative written in a structure or dramatic conventions employed in a great number of individual works(Cawelti, 1976:5-6). Small plot and large plot are two common usages which are closely related to the conceptions of the term formula. Small plot refers to common patterns which are usually quite specific to a particular culture and period and have different meaning in specific context. Meanwhile large plot specifies to the patterns that are not necessarily limited to a specific culture or period that can be found in manuals for writers who are still learning.

\section{The Artistic Characteristic of Formula Literature}

Cawelti stated that there are two core aspects of formulaic structures, essential standardization and primary relation to the needs of escape and relaxation or which is famous by the name of escapism (Cawelti, 1976: 8-9).

The first aspect is standardization. It refers to the similar understanding between writers and audiences. It is an important way in attracting the interest of the audiences that standardization reflects the sense of the story in the novel. This way is for increasing the audiences understanding and enjoying the details of a literary work. The work may give enjoyment for the reader. It brings of tracing historical trends or relating literary production (Cawelti, 1976: 8).

The second aspect is the needs of escape and relaxation. Escape or escapism is about the aesthetics taste in literary works such as a pleasure and enjoyment. A successful formulaic work needs to be unique despite of sharing same patterns with the rest of the literary works in the era and this can be 
reached when the addition of pleasure or escapism in the conventional structure or standardization can excite the readers, this can also result in a mimetic literature. Mimetic element in literature confronts us with the real world while the formulaic element reflects the construction of the ideal world. Cawelti said that formulaic works are always needed to be in an intense plot, so the readers will temporarily forget about their identities and fully be immersed in the imaginary world, meanwhile mimetic literature is miming the world that the readers are in, making them aware of themselves and their surroundings (Cawelti, 1976: 14). In other words, escapism serves the readers with enjoyment and pleasure needs without the readers feel the insecurities and sorrows of their real world.

\section{Typology of Literary Formula}

Cawelti (1976) mentioned formula can be an archetypal patterns that are represented in images, symbols, themes, and myths of a particular culture. In literary formula there are many types of stories centre on heroic action. Formulas are mostly conventional and oriented toward escapism where the authors create a world in which the fictional characters can relieve the readers' frustrations and concerns of their real lives, providing them with immense pleasure and enjoyment, for example when the heroes finally are able to defeat the villains or when the poor people is gifted with a lot of fortunes. Formula literature can also be mimetic. It is when there are some elements in the story that remind the readers about the real world, for example when Alice is stranded in another world, she still uses her knowledge of a seven years old girl to confront the creatures in that world which they do not work in a real world's moral. Looking at this range of story formulas, Cawelti (1976) in his theory decided to divide the primary moral fantasy into five types: 
Zafirna Arrofifah, Hat Pujiati, Irana Astutiningsih - Formulaic Structure in Thriugh the Looking Glass by Lewis Carroll

\section{Adventure}

Adventure story is the journey of the heroes which carry on some dangerous missions that full of achieve accomplishing some important and moral mission.

\section{Romance}

Romance is a fantasy of allunderstanding of love, most of stories that use this moral fantasy usually focus on the overcoming of the mix of social or psychological barriers.

\section{Mystery}

Mystery story is the hidden secretstory and investigation. Thecharacters try to solve a problemand have rational solution to unravel the unknown in order to have some answers.

\section{Melodrama}

Melodrama is the fantasy of a world that operates according to the desire in our hearts in contrast to the other formula types that are fantasies of particular actions or states of being that counter some of our deepest fears or concentrate on particular wishes.

\section{Alien Beings or State}

Horror story which usually uses some monster or alien to give a frightening impression to the readers. Readers use the fright and scare to escape momentarily from their real world which they already know if the story is not real so it also gives them the sense of security.

\section{Formulas and Culture}

In this theory, formulas and culture are closely related. Formulas themselves are cultural products and it can be a way of representing to create an effective story which can be determined by images, themes, symbols, and myths that are present in certain cultures. These points cannot be divided from certain formula of a literary work. 
There are many questions on the reason of popularity of a literary work. Cawelti (1976) proposed a way to identify a popular work as if we determine it only on the intrinsic elements alone it will be quite problematic. The way that is offered in this theory is the literary work has to be compared with other successful works in the same era, through the process of defining their elements or patterns, at least one basis for the popularity of a large number of works.

In his theory, Cawelti (1976) suggested the fourinterrelations hypotheses about the discussion between formulaic literature and the culture that produces the story while simultaneously enjoys it:

1. Formula stories affirm existing interest and attitudes by presenting an imaginary world that is aligned with these interest and attitudes.

2. Formulas resolve tensions and ambiguities from the conflicting interest of different groups within the culture or from ambiguous attitudes toward certain values.

3. Formulas enable the audience to explore in fantasy the boundary between the permitted and the forbidden and to experience in a carefully controlled waythe possibility of stepping across the line.

4. Literary formulas assist in the process of assimilating changes in values to traditional imaginative constructs.

\section{The Method}

Data analysed in this study consists of the selected narration, statements, and dialogues in Through the Looking Glass. For the secondary data, data include the glory of the Victorian era in children literature's publishing, and the Victorian values in journals and books published in printing or online. The first step to do in this analysis is close reading on the material object and collect data to classify them in two categories. The first category is the basic structure of the story especially plot, setting and characterization to trace the standardization of a formula of stories as proposed by Cawelti. The other category is the escapism of the story as the newness of the formula of stories. Then the next step is a 
Zafirna Arrofifah, Hat Pujiati, Irana Astutiningsih - Formulaic Structure in Thriugh the Looking Glass by Lewis Carroll

reading on the standardization of the formula that leads to map the story structurally. Furthermore, escapism of the standardization frames the analysis into a contextual one that is traced in the presentation of culture that is embedded in the form. The escapism pictures the cultural sphere as the reasons of the escape so that a dialectical method is needed to come and from text to context analysis. Finally, the reason of Through the Looking Glass become a popular work is answered as the previous step done.

\section{FINDING AND DISCUSSION}

The findings of this research show that Through the Looking Glass is a story that is constructed in an adventure pattern as the dominant archetype with fantasy as the additional element to build the tension of the story. The hero's efforts of going through the obstacle lead the story into the plot progress. The Chess land as the fantastic setting creates a plot chronology that is enigmatic motorizes the story with an adventure standard. While the escapism of a blending hero as antagonist as well as protagonist in a critical and philosophical ways across the limitations of Victorian rules in disciplining the hectic society because of the social revolution. The depiction of the creatures that is miming the repressive parents in Victorian culture entertains the readers from the rigid moral control of the Victorian.

\section{The Construction of the Formula in the Novel}

Cawelti (1976) stated that the story must be embodied in figure, setting, and situations that have appropriate meaning for the culture which produces them. Thus, breaking down the pattern of the novel should be done by using the components of standardization including plot, character and characterization, and setting. There are also three literary devices that are mostly used by formulaic writers-suspense, identification, and imaginary world (Cawelti, 1976: 17), making an embodiment of the figure deals with 
identification, setting deals with imaginary world, and situations deal with suspense.

From the analysis, the proof whether the pattern of the story is still presented in its standardization or it has strayed away from its convention will be given out, so that it can be concluded if the uniqueness is present.

\section{Plot}

Plot is one of the components that can be used to determine the standardization of a story, hence why plot is important. Plot sets in- exposition (beginning) - rising action - climax - falling action - denouement (ending) according to Freytag's Pyramid (1863) to make it easier to understand the story from the beginning of the story, the middle of the story, and the ending of the story as a whole story. Plot deals with suspense in the story and is widely used by formulaic writer.

1. The exposition shows the introduction of the character and setting. Alice is getting inside the Looking Glass world through the melting glass at this point of the story. This part is functioned to introduce Alice as the hero of the story which will go on an adventure in the Looking Glass world.

2. Rising action presents an increasing tension and uncertainty of the problem where protagonist should face. The offer Alice makes to Red Queen to be the queen while she has zero clue about the rules in Looking Glass world definitely add the tension to the story. Alice has to move from one square to another in order to become the queen on Eight Square and face obstacles in each square, this is a characteristic of an adventure story.

3. Climax is when the greatest tension and uncertainty appears in the story. Alice who finally reaches the Eight Square gets her crown as the queen, yet, this alone does not enough. The queens give her a test as more 
Zafirna Arrofifah, Hat Pujiati, Irana Astutiningsih - Formulaic Structure in Thriugh the Looking Glass by Lewis Carroll

obstacles and also make chaos in the feast party, hence why Alice is fed up and threatens to shake the most rude queen of the two, Red Queen.

4. Falling action of the story deals with the ending of the suspense where finally Alice can pay the price to Red Queen by shaking her with all of her might from her anger. This is where the hero finally stand up for herself without being submissive anymore.

5. Denouement shows the ending of the story using an open ending. The open ending shows Alice wakes up from the dream, back in her house, with her kitten. The question of who dreaming it is apparent in the end.

Using Freytag's pyramid, the plot of Through the Looking Glass shows a dramatic plot which means the story proggresses, keep moving forward from one event to another. In the end, the story uses an open ending which presents Alice wakes up from the dream after she is becoming a queen in a very short period of time in the Looking Glass world.

Based on the structure above, Through the Looking Glass is written by using adventure typology. It is proven by Alice as the hero progresses in each chapter to reach Eight Square and in each chapter she tries to face her obstacles, even putting herself in danger in some situations, and finally manages to be the queen.

\section{Character and Characterization}

Second literary devices relates to character and characterization which deals with identification in the novel.In order to analyze characterization, it can be concluded from the way the characters speak, think, act, and look.

Through the Looking glass has two kinds of creatures which can be constructed. The first one is the Looking Glass creatures which includes chessmen, talking animals, talking things, and supernatural being. Meanwhile the last one is mundane which is a human as a rational character. The characters from the fantasy world dominate the story within the novel. 
The main character of Through the Looking Glass is Alice, a 7-years-old girl. Alice is the protagonist character because she is the central focus of the story. In the beginning of the story, Alice is depicted as a child who is not conforming to usual type of a Victorian child. She is not gentle, timid, and docile, but rather she is written as an active, brave, and impatient little girl (Lurie, 1990: 7). Alice is also potrayed to be a child who has a lot of imagination and loves to play pretend. There is a sentimental side of Alice in the story which also decides what she has to do with another character, but she does not particularly have a romance interest in this novel. Alice is categorized as the hero in this novel. She has the bravery, witty mind, the imagination needed as a hero. However, she is merely a human child, Alice is not magical at all. To compensate from this, Alice has a briliant mind and imagination that she can be used to solve and face the obstacles.

The novel have the antagonist, which according to Porteous and Lindsay (2019) the role of antagonist in a text or a story is to act in opposition with the protagonist, mainly to interfere and obstruct the protagonist in achieving their goals. The creatures in Looking Glass world mostly are obstructing Alice the hero to get her goal done. Some of them even give obstacles to Alice which she has to face in order to go on to the next square. The involvement of antagonists in this novel also raises the conflict in which Alice often is trapped in an unwanted situation with and because of them. The antagonists are presented by Red Queen, White Queen, Tweedledee and Tweedledum, Sheep, Humpty Dumpty, and Guard as they are obstructing Alice's way by either making Alice feels small as an individual, scrutinize her to the point she feels uncomfortable and paralyzed in fright, or keeping Alice in their place despite of her protest and will to continue on her quest.

\section{Setting}

Through the Looking Glass is set in Victorian era (1837-1901) mainly takes place in the Looking Glass word. This book was written to help Alice Liddell 
Zafirna Arrofifah, Hat Pujiati, Irana Astutiningsih - Formulaic Structure in Thriugh the Looking Glass by Lewis Carroll

and her sisters - Edith and Lorina, to understand chess game easily. Using the creatures and Alice the character as a pawn, Carroll taught the girls about chess.

For a good amount of chapter one and chapter twelve, the novel takes place in real world, represented by Alice's house in England. Meanwhile for the rest of the chapters, the setting is in Looking Glass world. The Looking Glass world itself is full of creatures - animals, human-sized living chessmen, insects, and mythical creature like Unicorn. This is actually the world created from Alice's dream, where most of the creatures here are what Alice has witnessed or known in her life.

Chess has a significant theme in this novel. From the start, Alice has met the chessmen. The rulers of the land are chessmen. So, it is not a coincidence when the land is shapes as a chessboard as Alice claimed. Chess is one of the most favorable board games to play with family in Victorian era. Also, Lewis Carroll himself spent some times in his life to enjoy chess, written in his diaries and a letter to his sister. That is why chess is highly used here.

The setting in Through the Looking Glass is mostly done in a countryside like setting, as the woods taken up mostly the setting in this story.As a fantasy story, the boundaries between real world and fantasy world will always be marked with a border. The mirror in Alice's painting room act as a border between the two worlds, Alice's real word and Looking Glass world. Looking Glass world is created by adapting a chessboard as how Alice claims in the book if the land is like a huge chessboard, making Alice possible to move according to the rule of a chessmen, in her case, it is a pawn. If Alice decieds to move differently, she will get some surprising obstacles aside from the obstacles given by the antagonists. This setting is used as the construction in the novel to add the tension in adventure story.

Based on the elements above, the formula of Through the Looking Glass contains adventure and fantasy pattern, so this story is categorized as fantasy adventure story. From the plot's discussion, it shows that the story follows how an archetypal adventure story. Of course as a popular and widely loved book, 
there are some uniqueness in the novel that differed Through the Looking Glass from another book, for example The Water Babies by Charles Kingsley. Alice in the novel is a hero who uses her mind to face the obstacles, meanwhile some of the creatures are the antagonists who are on her way to become the queen.

\section{The Relation Between Popular Formula in Through the Looking Glass and the Popular Culture in Victorian Era}

The formula of the basic elements of the story gives distraction of the previous works in presenting adventure pattern. Through the Looking Glass presents a heroin who is critical and philosophical in an enigmatic way as a chess game movements for the motor of the plot. The distraction made in this standardization plot is a kind of escapism in a formula construction. Moreover, Through the Looking Glass construe the escapism at the level of opposing the standard value of the Victorian upon the relation of a child with their parents and also the society. The intertwine of the literary work as a poetic and its cultural background exist at the point of the use of language as media of the work. Language as a tool to express ideas shared in a society however also share social interest or point of view that can be so ideological for language is political. Therefore, a formula of a literary work is always cultural. The social changes is recorded in the work.

Agustin proves in her works using a formula theory by Cawelti that religious life of American is the poles of the plot in Cassandra Clare's The Mortal Instruments: City of Bone (2019) and also become the boost of the novels popularity. She argues in her work that it is the interpellation of ideologies in the novel that represents the society's point of view so that the communication of the work with the readers commensurable and the message is received. Inline with Agustin's argument, the result of this analysis shows that the cultural background becomes the booster of Through the Looking Glass's popularity. 
Zafirna Arrofifah, Hat Pujiati, Irana Astutiningsih - Formulaic Structure in Thriugh the Looking Glass by Lewis Carroll

The cultural background in the novel is mainly presented from Victorian era. Victoria's reign lasted so long that it comprised several periods, causing the Victorian age is not a one, simple, or unified era. Above all, it was an age of paradox and power (Landow, 2009). In Queen Victoria's reign time (1837-1901), Britain became industrialised, factories and scientific inventions took place, and railways were constructed which replaced traditional horse carriage as a long distance mode of transportation.Some expansions that were prevalent are inventions, religion, literature and arts, ideology, politics, and society.

A lot of people from rural area came to the cities because of the rapid growth of industries and jobs, resulting in the emerging of city population. Overcrowding in the1840s was especially bad, but slums remained a problem until well after Victoria's death. Social classes to divide people according to their jobs and social life could not be avoided, there were upper classes, middle classes, lower middle classes and ambiguous classes, lower classes, and underclasses.

Aside from the crimes and overcrowding, probably the most enduring and well-known idea about the Victorians concerns their prudish attitudes toward sexuality. Victorians were more reserved, if it is compared to thefreewheeling 18th century. They toned down the illicit sexuality and censored art and literature that discuss such topic (Frost, 2018: 1). This was coming from an Evangelical belief where women are deemed to be passive, dependent, nurturing, emotional, and moral, andso belonged in the private sphere. Men were aggressive, independent, competitive, rational, but not as intrinsically moral, and so belonged in the public sphere (Frost, 2018: 24).The fruit of this belief was a teaching of domesticity where men and women must marry under affection so the family would be full of love and managable through a long time. Through the natural spheres, women's role in this domesticity was to stay at home, managing the house and children. As a result, a lot of books were written for women, to guide them on becoming a good 
women and housewives. Women and children were urged to read since they spent most of their time home.

Children, however, has their parent's eyes on their back for almost of their childhood. According to Frost (2018), their parents were to much included in their lives to the point of overbearing and controlling. Children from different classes of parents had their own shortcoming, such as children would be shamed by their parents into better behavior rather than physical chastisement, sometimes with religious element teaching that could help, although this was different from family to family. They were educated by strict nanny, nurse, or governess if they have enough money or being sent to a boarding school based on their genders and usage. If they do not have enough money, they would be educated at home with the strict parents. Edmund Gosse's classic 1907 book Father and Son expressedhis frustration with his father's invasive religious scrutiny and Edmund'seventual rebellion against it. The work resonated with many readers whofelt smothered by parental expectations (Frost, 2018: 47).

Parents would do the best to teach their children to be a good person, one of the ways was through reading. This is understandable since their mother who stayed home with them were also urged to read. This was the reason why books and writers at Victorian era was increasing, despite of the heavy censorship from the queen. The other reason was from bussiness side, printing company found a way to do printing in a mass and easy way.

This caused the increase in children's literature. Mostly at the start, children's literature in the name of children's book was used to teach the children about religious and moral lesson. This was coming from the rise of the Sunday School Movement and other lateeighteenthcentury religious andeducational reforms(Lam, 2007).Until in mid-Victorian era where writers decided they should write for the children for fun, thus outpuring a lot of books that were mostly adventure, fantasy, fairy tales, and nonsense where children 
Zafirna Arrofifah, Hat Pujiati, Irana Astutiningsih - Formulaic Structure in Thriugh the Looking Glass by Lewis Carroll

could imagine instead of being burdened by moral and religious teaching (Patkus, 2015).

Through the Looking Glass was created when Carroll, under his real name Charles Lutwidge Dodgson, wanted to teach Alice Liddell and her sisters Edith and Lorina, about chess game. Chess had been a small part of Dodgson's life for awhile as he claimed in his diaries throughout 1866 (Wakeling, 1999). In order to teach the sisters in an easy way, Carroll thought it would be a lot more easier to teach using metaphorical fun fantasy story. In reality, however, his chess lesson in the novel is more unorthodox and not really applicable to the real game (Downey, 1998: 127).Even writing for fun, Carroll did not slip from criticism because a lot of writer critics at that era questioned a grown man writing a story for children. Mostly the criticism was about him writing for little girls instead boys. The criticism would date back to Carroll's life and the relationship between him and his mother. He could not shake the obsessive attachment for his seven sisters and mother (Weir, 1989). While this was untrue because Carroll suffers from a little bit difficulty to socialize with his peers (de Rooy, 1997), it is interesting to know how in its era Carroll as a children's book writer was seen as.

In the novel, Alice is perceived as a little girl who is highly criticalof her surroundings and of the adults she meets. She is different from how Victorian children are and should act according the Victorian culture. However, the characters the novel are mimicking how adults in Victorian era acted towards a child. They constantly try to subdue Alice into a good girl by either being angry, belittling, or reducing Alice's existence and knowledge when she starts to either question things or does not believe in them. Cawelti (1976) said that most formulaic works have at least the surface texture of the real work which Through the Looking Glass delivered perfectly. Carroll mimed one aspect of Victorian culture about parents in the book that is dedicated towards children in the guise of creatures in a strange land, where in the novel, the hero-Alice, 
is not surrendering to the creatures which can be depicted as the parents. Alice instead cleverly tries to fight back using her mind and her own way.

Through the Looking Glass' dominant pattern is adventure and fantasy as the standardization of the novel. Meanwhile, escapism is used to give the feeling of gratification to the readers, escaping their frustation of life. The construction of fantasy in this novel and the hero that is not conforming to the Victorian culture are what bringing the readers (mainly children) to escape their dull daily lives as Victorian children.

It has been explained in before that there are four interrelated hypotheses about the discussion between formula and culture produced while readers simultaneously enjoys it. Through the Looking Glass is related to first and third, the first point is formula stories affirm existing interest and attitudes by presenting an imaginary world with the alignedinterest and attitudes, literary formulas help to maintain culture's nature of reality and morality. In the imaginary world of Alice, the depiction of the creatures is still miming what parents do to teach and shape children in accordance with Victorian values. The fantasy adventure formula used in the novel is also prevalent in the Victorian culture for children's literature. Third point is formula enables the audience to explore in fantasy the boundary between the permitted and the forbidden, to experience carefully in a controlled way without overstepping this boundary. In the novel, Alice is becoming a disobedience child, unlike what is expected in Victorian values which based their moral teaching to the religious tract. This gives the Victorian children a chance to see what happens if they are being disobedient to their parents without risking themselves to be punished.

\section{CONCLUSION}

In this novel, the story is constructed by the use of adventure pattern as the dominant achetype with fantasy as the additional element to build the tension of the story. Through the Looking Glass is following the pattern that is pretty much used in the era, adventure archetype with fantasy. The heroes are 
Zafirna Arrofifah, Hat Pujiati, Irana Astutiningsih - Formulaic Structure in Thriugh the Looking Glass by Lewis Carroll

children that enter another different fantasy worlds filled with creatures and has one goal to fulfill. However, there are several differences. Alice does not need to die to enter Looking Glass world, she is simply sleeping and the world is a manifestation of her dream, there are no human adults in Alice's story, she is not a mythical creature nor turning into one, just a 7 years old human child. To make up this, Alice is using her mind and imagination to defeat the obstacles created by the antagonists. Based on the setting in the novel, the story tends to use Victorian countryside setting as the woods take up most of the place of the story. The chessboard land is also prominent setting as it is the drive for the story to progress.

The formula in Through the Looking Glass presents escapism that is longed by the Victorian children as their Victorian value is rather harsh to them. The depiction of the creatures that is miming the repressive parents in Victorian culture is giving the readers, that are mostly children, an understanding about the story. The escapism that is the fantasy world (Looking Glass world) mixed with chess game that is a favorite board game in Victorian era and Alice's characteristic to be a child who is courageous enough to question the creatures resonate with the children in Victorian era who wanted to be like Alice and tired of their dull life with their strict and repressive parents who commonly shamed and subdued them using religious teaching or Victorian morality. This gives them the chance to experience what if they disobeyed their parents without being punished, the third point of interrelation hypotheses of discussion between formulaic structure and the culture that produces while simultaneously enjoys it, formulaic stories give them a situation which they can enjoy the forbidden in the carefully controlled way so they will not overstep the boundary. That was why Through the Looking Glass was popular in Victorian era and still is popular in nowaday society as the reminicent of escapism, escaping the dull life the readers have to the world where they can be free of restriction or fight back. 


\section{REFERENCES}

Agustin, Linda. (2019). A formulaic structure analysis in Cassandra Clare's the mortal instruments: City of Bones. Jember: Universitas Jember.

Banerjee, Jacqueline. (2007). What is children's literature?. Victorian Web. Retrieved October 26, 2017, from http://www.victorianweb.org/genre/childlit/definitions1.html

Carroll, Lewis. (2014). Through the looking-glass (J. Tenniel, Illus.).Trans Atlantic Press. (Original work is published in 1871).

Cawelti, John G. (1976). Adventure, mystery, and romance: formula stories as art and popular culture. Chicago: University of Chicago Press.

de Rooy, Lenny. (1997). Frequently asked question (FAQ). Alice-inwonderland.net. https:// www.alice-inwonderland.net/resources/faq/\#drugs

Downey, Glen Robert. (1998). The truth about pawn promotion: the development of the chess motif in victorian fiction. (Doctoral Disertation, University of Victoria). UvicSpace. https:/ /dspace.library.uvic.ca/handle/1828/8275

Frost, Ginger Suzanne. (2018). The victorian world: facts and fictions. ABC-CLIO, LLC.

Lam, Siobhan. (2007). Be good, dear child. . or else.Victorian Web. Retrieved September 14, 2020, from http://www.victorianweb.org/victorian/genre/childlit/moraltales.htm $\underline{1}$

Landow, George P. (2009). Victorian and victorianism. Victorian Web. Retrieved September 18, 2020, from http://www.victorianweb.org/vn/victor4.html

Lurie, Alison. (1990). Don't tell the grown-ups: subversive children's literature. United States: Little, Brown \& Company.

MacDonald, A. (1989). Utopia through the looking glass: Lewis Carol As CryptoUtopian. Utopian Studies, (2), 125-135. Retrieved April 14, 2021, from http://www.jstor.org/stable/20718914

Morton, R. (1960). "Alice's adventures in wonderland" and "Through the lookingglass". Elementary English, 37(8), 509-513. Retrieved April 14, 2021, from http://www.jstor.org/stable/41385073

Patkus, Ronald. (2015). The age of alice: fairy tales, fantasy, and nonsense in victorian England. Vassar. Retrieved September 15, 2020, from https://specialcollections.vassar.edu/exhibit-highlights/2011-2015/ageof-alice/fairy-tales-fantasy-nonsense.html 
Zafirna Arrofifah, Hat Pujiati, Irana Astutiningsih - Formulaic Structure in Thriugh the Looking Glass by Lewis Carroll

Porteous, Julie and Alan Lindsay. (2019). Protagonist vs antagonist PROVANT: narrative generation as counter planning socially interactive agents track. Proceedings of the 18th International Conference on Autonomous Agents and MultiAgent Systems, Canada, 1069-

1077.http://www.ifaamas.org/Proceedings/aamas2019/pdfs/p1069.pdf

Spacks, P. (1961). Logic and language in "through the looking glass". ETC: A Review of General Semantics, 18(1), 91-100. Retrieved April 14, 2021, from http:/ / www.jstor.org/stable/42573885

Stevenson, Laura C. (2011). Literary ladders in the golden age of children's Book. United States: JHU Press.

Wakeling, Edward. (Ed.). (1999). Lewis Carroll's Diaries: The Private Journals of Charles Lutwidge Dodgson. Vol. 5. Lewis Carroll Society.

Weir, Marjorie N. (1989). Inside the ring: victorian and edwardian fantasy for children. (Doctoral Thesis, Simon Fraser University). Simon Fraser University Institutional Repository. https://core.ac.uk/display/56369089 